\title{
Impact of COVID-19 on Supply Chain of Major Horticultural Crops in Jammu and Kashmir, India
}

\author{
Bakhtaver Hassan ${ }^{1 *}$, Mahua Bhattacharjee ${ }^{1}$ and Shabir A Wani ${ }^{2}$ \\ ${ }^{1}$ Amity School of Economics, Amity University, Noida, Uttar Pradesh, India \\ ${ }^{2}$ Sher-e-Kashmir University of Agricultural Sciences and Technology of Kashmir, Srinagar, JEK, India
}

*Corresponding author: bakhtaverbaigh@gmail.com

Received: $01-03-2021$

Revised: 04-05-2021

Accepted: 09-06-2021

\begin{abstract}
This paper aims to highlight the disruption caused by COVID-19 in the supply-chain of major horticultural crops in Jammu and Kashmir, India which is the most important economic activity in the Union Territory. The paper studies the impact of COVID-19 on the pre-harvesting, harvesting and post-harvesting stages of horticultural supply-chain. Primary Data was collected through the telephonic survey whereby the farmers acknowledged delay in spraying the chemicals and fertilizers which has resulted in increase of pests and weeds in their farmers, This is likely going to impact the quantity as well as quality of the horticultural crops in Jammu and Kashmir. Another group of the respondents, who had stored last year's produce in Controlled-Atmosphere-Storages (CAS), have failed to find any buyer due to closure of the markets and the consequent fall in demand. The transportation and the storage cost of their stored produce is increasing with each passing day, therefore gradually eroding their profitability. Moreover, the cherry farmers who had reaped a good harvest couldn't find the buyers and therefore had to dump their produce hitting the economy badly. Longevity of COVID-19 and the subsequent lockdown is severely denting the efficiency of the supply-chain of the horticultural crops in Jammu and Kashmir. The profitability of horticultural sector as a whole is taking a severe hit which will impact the coming years too. With the pandemic yet to peak in India, the government should ramp up the infrastructure, provide timely input to the farmers, bring clarity in the opening of mandis and provide a financial stimulus to restore some normalcy in the sector.
\end{abstract}

Keywords: COVID-19, supply-chain, horticulture, apple, agriculture, storage-facilities, production

The global economic impact of COVID-19 which originated from Wuhan city in China is already perceptible across the sectors (WHO, 2020). The event is unique in economic parlance as both the demand as well the supply has fallen, possibly leading the world to a full-term recession much worse than Global Finance Crisis of 2008. The pandemic is already causing major disruptions in the socioeconomic and political scenario of the world. It is set to become one of the most economically costly pandemics, the world has ever faced. World-over, synchronised lockdowns and a sudden economic halt has rendered an unprecedented challenge for the economies at large. The current estimated impact on global GDP growth for 2020 is around $-4 \%$, with substantial downside risks if containment policies are prolonged. Output losses are larger for major economies (Boissay \& Rungcharoenkitkul, BIS, 2020; Atkeson, 2020).

\footnotetext{
How to cite this article: Hassan, B., Bhattacharjee, M. and Wani, S.A. (2021). Impact of COVID-19 on Supply Chain of Major Horticultural Crops in Jammu and Kashmir, India. Agro Economist - An International Journal, 08(01): 63-71.
}

Source of Support: None; Conflict of Interest: None 
Throughout the history, the pandemics have negatively impacted the society and the economy. The Spanish flu of 1918 which claimed upto 50 million lives resulted in a loss of 6 percent GDP and a combined 8 percent loss in the consumption growth overall in the world (Barro, Ursua \& Weng, 2020). SARS- Severe Acquired Respiratory Syndrome in 2003 claimed 800 lives in China and led to a loss of 0.1 percent in the world (Goldsmith et al., 2004). Ebola Virus which became widespread in West Africa led to a total of 12,000 fatalities in 2014-16 and an estimated 3 percent loss of GDP in Liberia, Sierra Leone and Guinea (Gunjal and Senahoun, 2016)

COVID-19 has already started a global recession as the borders are sealed from small districts to the country level. As already mentioned, the unique characteristics of the pandemic make it difficult to compare it with the global recessions like Global Financial Crisis of 2008 or even the epidemics the world has witnessed before. These characteristics like, one, it is a global pandemic impacting majorly the high-income economies. Two, the financial sector was already weak with historically low-interest rates. Three, the world is much more integrated. Most importantly, the pandemic has generated spill-over effect on the supply chains, hampering even the flow of the food-supply to the population worldover (McKibbin \& Fernando, 2020). In real economic sense, the impact can be gauged by the GDP foregone, which is the difference between the current forecasts and the forecast done before COVID-19. Accordingly, the annual output loss ranges between 4-5 percent globally which exceed the loss of 2.3 percent suffered during the Global Financial Crisis of 2008 (Boissay and Rungcharoenkitkul, BIS, 2020). With the current magnitude, nations strive to support their respective health-care system to curb the number of infections as well as the fatalities. In India, the growth rate is forecasted to fall from 7 percent to just 1-2 percent in the fiscal year 2020-21 (Hassan, The Wire, 2020). Overall, the economic impact of COVID-19 in India will depend on the sustainability and longevity of the virus, the subsequent disruption in supplychain network and the effectiveness of the policy responses.

In agricultural sector, the spread of pandemics restricts the access to farms and markets crippling the whole system which creates challenges for mobilization of food from the farms to the consumers, thereby hampering food-security of the population. These pandemics affect the overall production of agriculture as it disrupts the input-supply- labour, raw-material and timely capital to the farmers. Ebola Virus Disease, 2014-16 in West Africa resulted in a decrease of 7 percent, 12 percent and 10 percent in the production of wheat, rice and maize respectively (Gunjal \& Senahoun, FAO, 2016). Similarly, the Avian influenza virus, 2003 in South East Asia led to a fall of 15 percent in the poultry output in Thailand and Vietnam (Brahmbhatt, 2005, p.365). Moreover, to mitigate the impact of the Avian Influenza, the South-East Asian countries had culled 140 million birds which costed approximately 10 USD Billion. Consequently, the export trade of the poultry from these countries fell by 37 percent during the phase, 2004-06 (Goldsmith et al. 2004). The avian influenza in 2006 had resulted in mass culling of poultry and fall in demand which led to a loss of over 2200 crores INR to the Indian poultry industry (Mohan, Vishwanadham \& Trikha, 2009).

Like other economic sector, the unique double whammy of COVID-19 is witnessed in agriculture too. There is fall in both supply and demand for food which impact agriculture substantially, so there is possibility of food-insecurity across the globe (Brewin, 2020; Barua et al. 2020). It has affected all the segments of the food-supply chain, especially the midstream and the downstream segments. In developing world, since most of these food-supply chains are composed of informal sector, there would be lower foot traffic, lower income and substantial unemployment among the vast population (Reardon, Bellemare \& Zilberman, IFPRI, 2020). The supplychain disruptions, sealed borders and food-insecurity caused by COVID-19 will result in decrease of foodprices by 2.6 percent in 2020 (McKibbin \& Fernando, 2020).

Farmers will be hard hit with poor returns varying from one-third the usual or a complete loss. The stoppage of inter-district and inter-state transportation will drastically hit the commercial crops as they depend on better market access and migrant labour (Roy, 2020 Hindustan Times). COVID-19 has led to uncertainty and created high transaction costs in the food-supply chains in India. 92 percent of the food consumed in India is 
purchased, thus the disruption has put food-security in India at risk (Reardon et al. 2020). The production centers are shut, mining and manufacturing is closed and the agricultural activities are halted.

Across various states of India, there are reports of dumping of the agricultural produce in mass scale. The consequent lockdown imposed in India, has already delayed harvest of the rabi crops in the states of Punjab, Haryana, Karnataka, Uttar Pradesh (Roy, 2020, Hindustan Times). The impact will be visible in fruits like apples, cherries, bananas, pineapples and mango. Already, there has been mass-scale dumping of pineapple harvest in Kerala due to lack of proper marketing and transportation (S Ananth, 2020, Deccan Herald).

India is the fifth largest producer of Apple in the world and Jammu and Kashmir, is the leading producer of apple in the country, contributing 7075 percent to the total production in the country (National Horticulture Board, Horticulture at a Glance, 2018-19). Therefore, to study the impact of COVID-19 on supply-chain of apple crop, it is pertinent to analyze the supply chain of apple crop in Jammu and Kashmir. The supply-chain of apple is already suffering as farmers are unable to sell their produce in the market. Jammu and Kashmir economy in the broader perspective, is an importdependent export-oriented economy with a very large informal sector (Drabu, Greater Kashmir, 2020). The majority of the products produced in the Union Territory find markets outside the UT. This is true and infact significant for the apples produced in Jammu and Kashmir. Thus, supply-chain of the major agricultural products from Jammu and Kashmir will be drastically hit due to COVID-19 disruption (Hassan, The Wire, 2020).

Among the major supply-chains, apple is the one of the most dominant horticultural supply-chain in Jammu and Kashmir. Apple crop contributes nearly $60 \%$ to the total horticultural output in Jammu and Kashmir, from an approximate acreage of 50 percent. In 2018-19 the production of Apple from the region was 19 lakh tonnes, which is 77 percent of the total apple production in the country (Ministry of Agriculture, GOI). Annual export of apple from Kashmir fetches 7500 crores INR which is substantial for the state exchequer (Shaheen, Wani \& Kubrevi, 2019). The supply-chain of the crop in Kashmir consists of mainly six actors-inputsuppliers, farmers, commission agents, middle-men, mandis and finally the end consumer. Nearly, 38 percent of the total produce flows through FarmerMiddle-Men- Commission Agent- WholesalerRetailer- Consumer (Shaheen et al., 2019). Kashmir has been facing a consistent hiatus or strike of 2-3 months on an average in each year since 2008. The farmers face challenges in transporting their produce from their respective farms to the nearby Mandis/ Markets. Therefore, marketing of the apple crop is inadequate which leads to poor output-value per hectare (Sharma, 2016).

\section{MATERIALS AND METHODS}

\section{Sampling and Data}

Three main crops were selected which contributed nearly 90 percent to the total horticultural output from Jammu and Kashmir. For Apple and Cherry, primary data was collected through telephonic survey in three major apple producing districtsShopian, Anantnag and Kulgam. Multi-Stage Random Selection Technique was used to select the:

(a) Selection of 2 blocks, from each District.

(b) Selection of 3 villages, from each Block

(c) Selection of 5 farmers from each village.

From Kulgam District, Damhal-Hanjipora and Devsar blocks were selected. From Block DamhalHanjipora, Damhal, Gasran and Aadiguttan were selected. From Block Devsar, villages namely Akhal, Gangdaar and Sopat were selected. From District Anantnag, two blocks namely Shangus and Doru Shahabad were selected. In Shangus block, villages namely Shangus, Kihirbal and Nowgam, were selected. In Doru Shahabad Block, villages namely Kapran, Poolie and Sadiwara were selected. Finally, from District Shopian, Zainapora and Shopian blocks were selected. From Block Shopian, Pinjura, Dashipora and Kachdora villages were selected. From Zainapora Block, Hyderpora, Zainapora and Bongam were selected. The selection of the three districts was made to provide analysis of the impact of COVID-19 in areas directly affected as well as in areas indirectly affected. With the same logic, the villages from each district were chosen. Therefore, a total of 90 farmers each for Apple and Cherry were selected for the survey. 
Another sample of 20 farmers/respondents was taken who were awaiting to sell their last-year produce in this spring season stored in Controlled Atmosphere (CA). This dataset is different as only 3.5 percent of total produce of 2019 was actually stored in these CAs. A questionnaire was prepared and a detailed telephonic conversation with each respondent was held to get a comprehensive picture.

Secondary data was collected from Department of Horticulture, Jammu and Kashmir to assess the production of apple crop throughout the years. Data from National Horticultural Board and Ministry of Agriculture and Farmers' Welfare was used for understanding the importance of apple crop from Kashmir vis-à-vis its agricultural growth.

\section{RESULTS AND DISCUSSION}

\section{Supply-Chain analysis}

The existing supply chain of the apple crop is widely distributed and indeed very long in Jammu and Kashmir. The apple production and acreage has witnessed consistent increase throughout the last few decades. And the production is majorly dependent on certain variables universally, like cultivable area, input-output ratio, use of fertilizers, pesticides and irrigation. Considering production as the dependent variable and factors like fertilizers, pesticides, labour cost, credit-availability, market-distance and rainfall as independent variable, regression analysis was done.

The results show that the fertilizers and pesticides used by the farms considerably impact on the overall production of apple in Kashmir. Table 1, shows that fertilizers and pesticides, labour and market price of the produce are positively related to the dependent variable, production. With an increase of 1 percent in the fertilizers and pesticides, the production increased by 28 percent. Similarly, with an increase of 1 percent in the labour, the production increases by 21 percent. Meanwhile, rainfall per year is significant and negative, which determines that it is indirectly proportional to the production per year. Higher the rainfall by 1 percent, lower the production by 115 percent (Table 1).

The supply chain analysis presented above, gives an understanding of the major actors and their role in the overall crop production. Analysing the impact of the lockdown on each of the actor and the chain-action, the impact on production will be visible due to COVID-19. While majority of the dependent variables have been impacted by the current lockdown, there are natural variables like rainfall and other variables like irrigation of the orchards which are independent of the lockdown. The analysis provides an insight of the viability of the supply chain in the production of the crop in Kashmir. With the current lockdown forced due to the destructive COVID-19, the paper therefore analyzes the impact of the lockdown on each of the supply-chain action and thereby the impact on the production of the apple during the pandemic.

\section{Classification of farmers}

The classification of farmers according to their landsize alongwith the total percentage of land used in cultivation of apples and percentage of the income earned from apple cultivation is presented in Table 2 . The small and marginal farmers (50 percent), lead the diversification of their land, 80 percent of their total land aggregate is used in harvesting apples.

The number is significant as it gives an understanding of the importance of apple-cultivation for these small and marginal farmers. The income of the small and marginal farmers from apple cultivation is however lower than the medium and large farmers, implying that there are external factors which enable them to produce at market-surplus level. However, the average income of the respondents from apple cultivation is 65 percent which is substantial for their livelihood. Therefore, any disruption in the supply-chain will directly affect the livelihood of these farmers (Table 2).

\section{Impact on pre-harvesting planning and expected production}

Covid-19 (Coronavirus) has hit Kashmir on the onset of the spring season when the farmers are usually busy in pre-harvesting activities. These activities involve spraying of pesticides, fertilizer application and tilling of the land to weed out the harmful and unwanted plants from the orchards. This preparation stage is important for high returns and a bounty crop to the farmers, as it impacts both the production as 
Table 1: The extent of the impact of COVID-19 Lockdown on Pre-Harvest Planning and Production

\begin{tabular}{llll}
\hline \multicolumn{1}{c}{ Particulars } & Yes & In Between & No \\
\hline Farmers who couldn't spray fertlizers and pesticides on time & $31(77.5)$ & $6(15)$ & $3(7.5)$ \\
Farmers who sprayed cheaper fungicides and pesticides & $22(55)$ & $12(30)$ & $6(15)$ \\
Farmers who couldn't till on time & $23(57.5)$ & $10(25)$ & $7(17.5)$ \\
Most roads closed down & $15(37.5)$ & $18(45)$ & $7(17.5)$ \\
Farmers with Monoculture & $18(45)$ & $8(20)$ & $14(35)$ \\
Growth of Unwanted Grass and Weeds & $16(40)$ & $12(30)$ & $12(30)$ \\
Labour Availability & $7(17.5)$ & $15(37.5)$ & $18(45)$ \\
Pest population increased & $20(50)$ & $12(30)$ & $8(20)$ \\
Expected fall in production & $23(57.5)$ & $5(12.5)$ & $12(30)$ \\
\hline
\end{tabular}

Source: Survey, 2020.

Table 2: The extent of impact of COVID-19 on Marketing and Transportation of Apple

\begin{tabular}{llll}
\hline Particulars & Yes & No & Not sure \\
\hline Farmers who couldn't sell their stored produce of last year & $13(65)$ & $5(25)$ & $2(10)$ \\
Farmers who couldn't find any buyer in the market & $14(70)$ & $2(10)$ & $4(20)$ \\
Inflated Transportation Cost & $11(55)$ & $4(20)$ & $5(25)$ \\
Most roads closed down & $15(75)$ & $3(15)$ & $2(10)$ \\
Unaffordable Storage cost & $16(80)$ & $3(15)$ & $1(10)$ \\
\hline Expected Dumping of the produce & $12(60)$ & $4(20)$ & $4(20)$ \\
\hline
\end{tabular}

Source: Survey, 2020.

well as the quality of the produce. The likely impact of the lockdown will affect the midstream of input supply chains such as fertlizers and seeds which will hurt the farmers (Reardon et al. 2020).

With the country in the third phase of the lockdown, 77.5 percent of the farmers couldn't spray fertlizers, pesticides and fungicides in their orchards on time at all, while another 15 percent had to delay the spray to a large extent. Only 3 percent of the farmers sprayed on time. Due to closure of the markets, the farmers failed to reach to the distributers, while duplicate products proliferated in the market. Therefore, the 55 percent chose cheaper pesticides and fungicides for their farms completely, while 30 percent chose a mixture of the two for balancing their income as well as the expenditure. Only 15 percent of the farmers however chose quality fungicides and pesticides for their farms, which they usually would have chosen in normal circumstances. From the regression analysis, (Table 1), fertilizers and pesticides are extremely important for the production and as already mentioned, a percent increase in the fertlizers and pesticides leads to a 28 percent increase in the production. Therefore, the lockdown has impacted the timely use of the fertlizers and pesticides, which is likely to impact the production of apple this year.

Tilling of the orchards, particularly around the apple trees is an important aspect of orchard management. It prepares the soil around the trees for new amendments, aerates the soil, helps the bio-activators to perform their activity for the fertility enhancement and weeds out unwanted plants or weeds around the trees. 55 percent of the farmers couldn't till on time, as the tilling machines were unavailable, petroleum stations were closed and there was shortage of labourers in the market. Only 7 percent of the farmers have tilled on time. Labour shortage in the farms was visible in all the three phases of the lockdown for plausible reasons. One, that there were redzones and buffer zones announced which impaired labour-movement and forced home-quarantine of the farmers. Two, the farmers being aware of the 
contagious nature of COVID-19 were apprehensive of letting labourers work in their farms. However, in small and marginal farms, family labour is usually used and therefore, they didn't face any major labour shortage. 45 percent of the farmers faced no challenge of labour-shortage during this phase (Table 3).

The farmers are already witnessing the impact of untimely and low-quality use of pesticides and fungicides. 40 percent of the farmers witness growth of unwanted grass and weeds while another 50 percent witness increase of pests in their farms. Only 10 percent of the farmers witness minimum or no growth of weeds while only 20 percent witness no additional increase of pests in their farms. Apple crops are the most vulnerable to such attack of pests and fungi, as the taste as well as the texture of the apples plays a major role in its marketing. Further, apples with scars and scabs are graded poorly in the market which affects the overall returns of the farmers. The prevalence of monoculture among the farmers makes the orchards more susceptible to disease (Mir and Mir, 2018). 45 percent of the farmers have grown only one variety (Red-Delicious) of the apple in their farms (Table 3). Unfortunately, the red-delicious is one of the most vulnerable variety to diseases (Mir and Mir, 2018).

These factors are extremely significant for a quality and bounty harvest; therefore, 57.5 percent of the farmers expect a fall in their production, 12.5 percent expect that the production will likely be impacted to some extent, whereas only 30 percent of them were optimistic that the production will not see any fall. This endorses the outcome of the study by Ngegba, Bangura \& Moifray, (2015), which concluded that the Ebola Virus Disease had severely affected pre-harvesting and harvesting activities in the quarantined communities. As lack of labour and pesticides spraying had caused increase in the population of the pests and rodents. Even the study conducted by Gatiso et al. (2017), endorses the findings that the Ebola like virus diseases forces farmers to stay indoors, therefore hampering the economic activities across Liberia.

\section{Impact on harvesting and post-harvesting}

Farmers and traders store some of the produce in November-December, post harvesting season to sell it in next March-May period to ensure that they get better price for their produce (Mir, 2013; Shaheen et al. 2019). With the onset of the Controlled Atmosphere Storage (CAS) this practice is often practiced by the farmers and the traders where they pay some price per box for storage in these CAS.

Nearly, 65 percent of the farmers and traders who had stored part of their produce in CAS, have not been able to sell their produce on time. The closure of the markets and the restricted movement in the mandis have created doubts among these farmers/ traders and as a result they are still paying for their storage at ₹ 30/box of apple. Among these respondents, another 70 percent couldn't find a single buyer in the market post March, $25^{\text {th }}$ amidst the lockdown (COVID-19). Only 10 percent of these farmers and traders, were able to find a seller for their last year produce. Even more unfortunate is that, 55 percent of the farmers who were able to reach to the market found that the transportation cost was escalated to 200 percent from $₹ 20,000$ to ₹ 60,000 .

Table 3: Controlled Atmosphere Storage in Kashmir

\begin{tabular}{lll}
\hline Name of the CA Facility & Location & Capacity (MT) \\
\hline Valley Fresh Cold Chain Pvt. Limited & Lassipora, Pulwama & 5000 \\
I-Fresh Kehwa Square Pvt. Limited & Lassipora, Pulwama & 6000 \\
Golden Apple Agro Fresh Pvt. Limited & Lassipora, Pulwama & 8000 \\
Harsha Natural Agri Service Pvt. Limited & Lassipora, Pulwama & 7000 \\
Fruit Master Agro Fresh Pvt. Limited & Lassipora, Pulwama & 5000 \\
Shaheen Agro Fresh Pvt. Limited & Lassipora, Pulwama & 8000 \\
Kashmir Premium Apples Pvt. Limited & Lassipora, Pulwama & 7000 \\
FIL Industries Pvt. Limited & Rangreth, Budgam & 5000 \\
\hline TOTAL & & 51000 \\
\hline
\end{tabular}


The storage cost of the produce is further creating financial problems for these farmers/traders. With each passing day the storage cost is rising which is slowly lowering their expected net return, thus eroding their profitability. 80 percent of the respondents feel that the storage cost is already ruining their profitability. Another, 60 percent of the respondents expect that with the lockdown likely to be extended, they will have to dump their produce as their cost outrun the total revenue they expect to receive even if they are able to sell their produce.

Amidst such chaos and uncertainty in the market, the production and the harvesting of the crop will likely suffer. The provision of long lockdown and the self-quarantine amongst the farmers will likely create suspicion among the farmers for hiring labourers from the adjoining villages in the coming months. According to the farmers, there are experienced workers working during the post-harvesting period in grading and sorting of the apples. There are apprehensions that some of the farmers might face shortage of those experienced workers in their farms which might affect grading of the apples.

\section{Impact on marketing}

COVID-19 will substantially affect the farms indirectly, through several channels. The effective demand from consumers will be constrained significantly due to reduction in consumers' real incomes in the crisis. This impact will be felt strongest among perishable products such as milk, fruits and vegetables, fish and chicken which need more handing and are more elastic in demand (Reardon, EPW , 2020). The failure of the farmers (65 percent) to sell their last years' stored apples during the crisis is a manifestation of this (Table 4). The fall in demand of apples from Kashmir is going to badly hit the 9000 crore INR industry in the Union Territory. Currently, with 3.5 percent of the apples stored in CAS, there would be a loss of 1000 crore INR even before the start of this agricultural season (Hassan, 2020, The Wire). Even more pronouncing will be the impact on the future marketing of apple from Kashmir.

Nearly, 75 percent of the crop is exported to the rest of the country and 85 percent of the harvested crop is transported immediately in the months from October to November due to lack of cold storage and proper infrastructure (Bhat, 2014, p.32). There are only two terminal markets working in the entire Union Territory of Jammu and Kashmir. One of them is Parimpora Fruit Mandi in Srinagar and the other one is Narwal Mandi in Jammu (Bhat and Choure, 2014). Provision of local mandis is crucial to maintain some semblance of the existing supplychain which benefits the farmer in selling his produce easily during the disruption due to an epidemic or pandemic (Reardon et al. 2020). With lack of local collection centers at the Village and Block level, the farmers will find it difficult to sell their produce at optimum prices.

Adequate infrastructure in the supply-chain mitigates the seasonal or cyclical disruptions as it enables farmers to store their produce for better marketing (Mir and Mir, 2018). Proper storage enables farmers to fight seasonal glut, deflation and short-term supply side strains due to pandemic (Gunjal \& Senahoun, FAO, 2016). Therefore, for the apple industry in Kashmir, adequate modern-infrastructure is important to prevent any large-scale dumping of the produce. But, the Controlled-Atmosphere storage registered under the government in Kashmir Valley is just 52000 MTs. There are other numerous CAs within the Valley catering to different regions, with total CAS, accommodating just 3.5 percent of the total production of the Union Territory. With the current pandemic, the longevity of the closure of the markets raise certain issues. The farmers as a result, may be forced to store their produce until the market-chain returns to normalcy in 2021 (Reardon et al. 2020). But the lack of adequate storage of apples in Kashmir will force the farmers to sell and dump their produce at extremely low price. This will likely impact the livelihood of all the actors, farmers, traders, commissioning agents and even the consumers. The farmers will be the worst hit as they will have to dump their produce due to lack of proper infrastructure.

\section{CONCLUSION}

COVID-19 has disrupted the food-supply chain in India as well around the globe. Farmers are left alone in their fields waiting for the government support. In Kashmir, the disruption of supply-chain of apple industry is imminent. There is delay in spraying of the pesticides, fungicides and fertlizers in the apple orchards which is hurting the farmers. 77 percent 
farmers have already witnessed a delay in the input supplies, while nearly 60 percent have chosen cheaper products on account of restrained incomes in the crisis. 50 percent of the farmers have already witnessed an increase in the pests while another 40 percent have witnessed increase in the unwanted grass and weeds. Therefore, witnessing such unfortunate impact in the pre-harvesting phase, 60 percent of the farmers expect a fall in the production and productivity. This can be confirmed from the results in the regression analysis, which point out the importance of these inputs to the farmers.

Another batch of the respondents are witnessing difficulty in selling their last-year's produce stored in Controlled Atmosphere. 65 percent of the respondents have directly failed to sell their produce on time and as such there are chances that these farmers might be forced to dump their produce leading to a loss of 1000 crore INR. Transportation costs have escalated to 200 percent which impacts the overall profitability of the sector. Further, the longevity of the storage increases the cost of storage, eroding the profitability of the crop.

With COVID-19 staying longer than expected, the supply chain will be disrupted for long. The current storage facilities in Jammu and Kashmir, especially the Controlled Atmosphere Storage is almost negligible at 3.5 percent. With the current harvest on the anvil in the coming months, the farmers would require better storage facilities to arrest the glut in the market. They require proper storage facilities to ensure that they supply their produce only when the demand picks up. Further, the lockdown and the spread of the virus in the rural areas might impact the labour availability during the harvesting phase. This will overall hurt the farmers.

The government needs some concrete steps to ensure that the apple industry of Jammu and Kashmir does not suffer heavy losses. First, on the priority basis the government should ensure that there are pesticides, fungicides and fertlizers available at local registered shops. The quality of these input supplies should be duly checked and duplicate products should be identified. At the Tehsil and the Block level, agricultural extension services should be started with due consideration to social distancing measures to provide knowledge to the farmers and ensure that there is minimum panic among the farmers. Second, the government should a announce relief package for the farmers, traders involved. This includes moratorium on their loans with proper holiday from the interest too. Third, the government should provide a proper plan of procuring the appleharvest of the upcoming season. This would bring in confidence among the farmers to work judiciously in their farms. Procurement by NAFED, as they did in 2019 is an important step to relieve farmers from the pressure of unavailable markers and expected lack of demand. Even if the government procures 90-100 percent of the apple produced (9000 crores) the expenditure will be just 1.5 percent of the GrossState Domestic Product (Economic Survey, 2017-18, Jammu and Kashmir). This is possible only when the central government intervenes at the right time.

The government should facilitate transportation of the already stored apple-boxes in the Controlled Atmosphere. Proper monitoring and ease of interstate movement of these fruit-laden trucks should relive the farmers in recovering some of the revenue. Agricultural Mandis should facilitate the sale and auctioning of these apples under proper scrutiny and guidelines of the health-officials. The government should also leverage the private sector and make necessary arrangement for the development of the infrastructure in order to ensure that the applefarmers do not suffer. Horticulture is the back-bone of the agrarian economy of Jammu and Kashmir, and the apple-crop is the most dominant crop in the Valley. Therefore, proper arrangements should be made to ensure that the supply-chain of apple industry doesn't suffer.

\section{REFERENCES}

Atkeson, A. 2020. What will be the economic impact of COVID-19 in the US? Rough estimates of disease scenarios (No. w26867). National Bureau of Economic Research. https://doi.org/10.3386/w26867.

Barua, S. 2020. COVID-19 pandemic and world trade: Some analytical notes. Available at SSRN 3577627. https:// dx.doi.org/10.2139/ssrn.3577627.

Barro, R., Ursua, J. and Weng, J. 2020. Coronavirus Meets the Great Influenza Pandemic. VoxEU. org, 20.

Bhat, T.A. and Choure, T. 2014. Status and strength of apple industry in Jammu and Kashmir. International Journal of Research, 1(4), 277-283.

Bhat, T.A. 2014. Economic of Apple Industry: A Primary Survey in District Shopian Kashmir (India). Higher Education, 17: 34. 
Boissay, F. and Rungcharoenkitkul, P. 2020. Macroeconomic effects of Covid-19: an early review (No. 7). Bank for International Settlements.

Brahmbhatt, M. 2006. Economic impacts of avian influenza propagation. In First International Conference on Avian Influenza in Humans.

Brewin, D. 2020. The impact of COVID-19 on the grains and oilseeds sector. Canadian Journal of Agricultural Economics/Revue canadienne d'agroeconomie.

Drabu, Haseeb, 2020. “Combating Covid-19: The Economic Dimension”, Greater Kashmir, Retrieved from: https:/ / www.greaterkashmir.com/news / latest-news / combating-covid-19-the-economic-dimension-2/.

Gatiso, T.T., Ordaz-Nemeth, I., Grimes, T., Lormie, M., Tweh, C., Kühl, H.S. and Junker, J. 2018. The impact of the Ebola virus disease (EVD) epidemic on agricultural production and livelihoods in Liberia. PLoS Neglected Tropical Diseases, 12(8).

Government of India, Ministry of Statistics, Planning and Implementation, National Sample Survey Office (2019): "Gross Domestic Product Report".

Government of India, Ministry of Finance, Economic Survey of India-2019-20: "Agriculture and Allied Sectors."

Government of India, Ministry of Statistics, Planning and Implementation, National Sample Survey Office (2019): "Horticulture at a Glance, 2018."

Goldsmith, C.S., Tatti, K.M., Ksiazek, T.G., Rollin, P.E., Comer, J.A., Lee, W.W., ... and Zaki, S.R. 2004. Ultrastructural characterization of SARS coronavirus. Emerging Infectious Diseases, 10(2): 320.

Gunjal, K. and Senahoun, J. Assessing the impact of infectious disease outbreaks on agriculture and food security: The case of the Ebola virus disease outbreak in West Africa, FAO. https:/ / dx.doi.org/10.1481/icasVII.2016.g45d.

Hassan, W. 2020. Kashmir: COVID-19 Lockdown Adds to Woes of Apple Growers and Trader, The Wire, Retrieved from, "https://thewire.in/agriculture/ kashmir-covid-19-lockdown-apple-traders".

Hosono, H., Kono, H., Ito, S. and Shirai, J. 2006. Economic impact of Nipah virus infection outbreak in Malaysia. Proceedings of the $11^{\text {th }}$ ISVEE.

Jan, I. and Manig, W. 2008. The Influence of Participation in Agricultural Support Services on Income from Agriculture: Results from the Multiple Regression Model (A Case from Rural Northwest Pakistan). Sarhad Journal of Agriculture, 24(1): 129.
Landau, S., Mitchell, R.A.C., Barnett, V., Colls, J.J., Craigon, J. and Payne, R.W. 2000. A parsimonious, multipleregression model of wheat yield response to environment. Agricultural and Forest Meteorology, 101(23): 151-166.

McKibbin, W.J. and Fernando, R. 2020. The global macroeconomic impacts of COVID-19: Seven scenarios. https:/ /dx.doi.org/10.2139/ssrn.3547729.

Mir, D.P.A. and Mir, A.A. 2018. Critical Issues in the Supply Chain Management of Kashmiri Apple: An Exploratory Study. Researchers World, 9(2): 22.

Mohan, U., Vishwanadham, N. and Trikha, P. 2009. Impact of avian influenza in the Indian poultry industry: a supply chain risk perspective. International Journal of Logistics Systems and Management, 5(1-2): 89-105.

Ngegba, M.P., Bangura, E.T. and Moiforay, S.K. Impact of Ebola on Farm Productivity as perceived by farmers and extension agents in Sierra Leone. Global Journal of Bioscience and Technology, 4(4): 406-411.

Shaheen, F.A., Wani, S.A. and Kubrevi, S.S. 2019. The landscape of agro-processing industries in Jammu \& Kashmir. Agricultural Economics Research Review, 32(conf): 175-182.

Reardon, T., Bellemare, F.M. and Zilberman, D. 2020. How COVID-19 may disrupt food supply chains in developing countries. International Food Policy Research Institute. https://www. ifpri. org/blog/how-covid.

Reardon, T. 2020. COVID-19's Disruption of India's Transformed Food Supply Chain. Economic and Political Weekly.

Roy, and Guha, A. 2020. "Covid-19 hits tea and pineapple farmers in Bihar; farmers dump produce". Retrieved from: https:/ / www.hindustantimes.com/india-news/ lockdown-hits-tea-pineapple-growers-in-biharfarmers-dump-produce/story. html.

WHO - World Health Organization, 2020a. Novel Coronavirus (2019-nCoV). Situation Report - 1. 21 January 2020. 5 pp Retrieved from : https://www.who.int/ emergencies/diseases/novel-coronavirus-2019/ situation-reports/. 
